\title{
« What a Catch! »: A Case Report on Denial and Myocardial Infarction
}

\author{
Naviaux A-F $F^{2,3}$, Banse $E^{4}$, Guedes $A^{2,5}$, J anne $P^{4 *}$, \\ Gourdin $\mathbf{M}^{1,2}$ \\ ${ }^{1}$ Department of Anesthesiology, Université Catholique de \\ Louvain, Belgium \\ ${ }^{2}$ Faculty of Medicine, Université Catholique de Louvain, \\ Belgium \\ ${ }^{3}$ College of Psychiatrists of Ireland, Health Service \\ Executive (HSE) Summerhill Community Mental Health \\ Service, Ireland \\ ${ }^{4}$ Faculty of Psychology, Université Catholique de Louvain, \\ Place Cardinal Mercier 10, Ottignies-Louvain-la-Neuve, \\ Belgium \\ ${ }^{5}$ Department of Cardiology, Université Catholique de \\ Louvain, Belgium \\ *Corresponding author: Pascal J anne, Professor, \\ Université Catholique de Louvain, CHU UCL Namur, \\ Avenue Dr G. Thérasse, B. 5530 Yvoir, Belgium
}

Received: March 16, 2021; Accepted: May 07, 2021;

Published: April 14, 2021

\section{Background}

Coronary disease has long been associated with different behavioral patterns (Pattern A, D) and denial mechanisms. Denial can take various forms that put the coronary patient at risk during the whole course of his illness $[1,2]$.

\section{Objective}

This case shows to what extent denial mechanisms can interfere in the relationship between some coronary patients and their caregivers.

\section{Case Presentation}

Roger, - now deceased - would have been 95 this year and had two heart attacks. His first infarction was anteroseptal, while his second was an inferior infarct. He suffers from coronary disease and has a history of unstable angina. He had a double coronary bypass (saphenous vein graft on left anterior descending artery and right coronary artery.). Heart wise, when we met him, he was currently symptom-free but presented a dyspnea of grade II to III. He denied any ongoing chest pain even during moderate effort.

We assessed Roger in the context of his heart surgery. We met him in Intensive Care Unit both before and after the intervention. During the postoperative phase, he described his second heart attack. He really enjoyed telling us the story of his second infarction, which occurred while he was already on antianginal medication (i.e. Cedocard'). It all started while he was angling during the weekend.

Roger had been fishing for several hours but had not caught anything. He was upset and about to leave (Pattern A typical impatience) [1-3] when all of a sudden, he felt his line snapping tight for a split second: a line bite! The trout was, allegedly, huge, and his fishing rod was too light to land the fish in one go. Being a strategic angler, Roger decided to wear the fish down and to slowly bring it back to shore so that he could scoop it with his landing net. While doing so, he felt the first angina pain occurring and persisting. $\mathrm{He}$ tried to reach for his tablets in his pocket but could not manage as his hand was already benumbed. He explained: « At that stage, I told myself: Roger, it's you or the trout! » Well, he went for the trout! He landed the fish first (after a one-hour struggle) and only then agreed to go to hospital in emergency (if this term remains appropriate in such a context).

\section{Discussion}

In this case, the patient is very proud to explain how he replaced our medical rationale (requesting emergency hospital admission) with his own set of priorities. His attitude might appear suicidal to his care providers, but reflects perfectly the psychological aspects of the coronary patient.

Our case report aims to demonstrate how far denial can thrive and conflict with medical and scientific reasoning [4]. This clinical case speaks volumes for the different views patients and caregivers can have on a same subject. In a mental dialectic, the patient typically prioritized his leisure imperatives and his desire to be victorious over his health necessities. In the same denial mechanism, the drive for life and the death wish co-exist at the same time, while the action proves how the pleasure principle overtakes the reality principle. According to psychoanalysts' works, the denial process in this case could hardly be considered solely unconscious. Furthermore, it is the patient himself, who consciously highlights the notion of self-destruction through his narrative.

From a specialist's point of view, the patient's behavior appears as a total denial of his symptoms, of his disease and of the required treatment; the patient puts his life in danger. In contrast, others might see in this case report a strong affirmation of the self and of the desire, associated to a behavior driven by life instinct, a non-acceptance of a « semi-life » such as prescribed by the physician: no salt, no smoking, no alcohol, no prolonged exertion, (no sex?). However, could this consideration be sustainable?

When the patient wonders « Roger, it's you or the trout? », it can simultaneously be considered as a suicidal behaviour and a way for the subject to keep his life meaningful and to remain the master of his destiny [5].

\section{Author's Contribution}

Maximilien Gourdin, Anne-Fréderique Naviaux, Emile Banse, Antoine Guedes and Pascal Janne conceived and drafted the manuscript. Anne-Frédérique Naviaux translated the manuscript. All the authors contributed to the literature review, critically revised the manuscript regarding intellectual content, approved the final version to be published and agreed to act as guarantors of the work. 
Antoine Guedes and Maximilien Gourdin particularly focused on the cardiological aspects of this case report. Anne-Frédérique Naviaux, Emile Banse and Pascal Janne centered their work on the psychological and psychiatric aspects of this case report.

\section{References}

1. Levine J, Warrenburg S, Kerns R, Schwartz G, Delaney R, Fontana A, et al. The role of denial in recovery from coronary heart disease. Psychosom Med. 1987; 49: 109-117.
2. Rosenman RH, Friedman M, Straus R, Jenkins CD, Zyzanski SJ, Wurm M. Coronary heart disease in the Western Collaborative Group Study. A followup experience of 4 and one-half years. J Chronic Dis. 1970; 23: 173-190.

3. Blumenthal JA, O'Toole LC, Haney T. Behavioral assessment of the type A behavior pattern. Psychosom Med. 1984; 46: 415-423.

4. Saxe JS. Denial. Annals of Internal Medicine. 2017; 167: 828-829.

5. Beisser AR. Denial and affirmation in illness and health. The American Journal of Psychiatry. 1979; 136: 1026-1030. 